\title{
LITERATURE
}

\section{Dorota Osińska}

\section{"Then Thickest Dark Did Trance the Sky": a Representation of Psychological Decay in Alfred, Lord Tennyson's "Mariana"}

\begin{abstract}
The Victorians openly expressed their deep fascination with the study of the mind which was reflected in the rise of the nineteenth century "Psychological School of Poetry." One of the authors who was captivated by the question of mental disorders was Alfred, Lord Tennyson. Despite the extensive research on his poetry, "Mariana" tends to be overlooked and reduced to a mere depiction of unbearable loneliness. However, this study focuses on the way how Tennyson, by using different modes of representation such as visual, auditory, and temporal, indirectly portrays a degradation of the protagonist's psyche, thus showing that the mental state can be expressed by the external images of a surrounding landscape, not by a character's subjective perception. By the close reading of the poem as well as comparing the description of psychological disintegration with another well-known heroine of the Victorian era, Miss Havisham from Charles Dickens's Great Expectations, one may conclude that the conveyed imagery of decay and blight mirrors the gradual psychological downfall of the female character. Contrary to Harold Bloom's reading of the poem, I will argue that Mariana's tragedy lies precisely in her retreat from the external world and dwelling in the vicious circle of her predicament which reinforces the character's masochistic coping mechanisms. Above all, the power of the poem lies not in the immediate shock and disgust, but in evoking a sense of moroseness that slowly kills the protagonist.
\end{abstract}

Keywords: Victorian, literature, poetry, psychology, isolation, Tennyson, XIX century 


\section{Introduction}

What would happen to the individual's psyche if one retreated from society into a remote landscape? Is it always the case that loneliness helps to discover oneself? The decision to withdraw can arise from different reasons, including religious beliefs and other conscious choices. The Greeks, for instance, among them Plato and Aristotle, argued that being alone creates a perfect opportunity to discover oneself and the surrounding world. In the Judeo-Christian tradition, loneliness is connected with the wilderness of the desert and desolate landscapes, thus providing the perfect circumstances for spiritual purgation. Renaissance thinkers, notably Michel de Montaigne or Petrarch, claimed that detachment and sociality are interdependent. Montaigne particularly stressed that solitude is a way to prepare oneself for participating in the community. Paradoxically, to appreciate society one should seek loneliness.

On the other hand, excessive loneliness can be damaging for the individual. The Enlightenment philosophers, for instance Adam Smith and David Hume, would claim that separation poses a potential threat for the good of the society. According to these eighteenth-century intellectuals, solitude tends to inflate one's ego and deprives people of the opportunity to accurately judge the behaviour of others. Conversely, the Romantic poets argued that loneliness should be embraced and celebrated, especially in connection with nature as well as imagination (Bragg 2014). Despite its alluring quality, intense loneliness tends to consume human beings. In fact, people are social creatures who, above all, aim at forming meaningful connections with people. In other words, feelings of being isolated from the community or from significant others can have numerous negative implications, including physiological, social, and psychological ones (Cacioppo and Patrick 2008, 5). ${ }^{1}$

In 2016, Olivia Laing, a British culture critic, examined the peculiar impact of loneliness on the individual and its relationship with creativity. In her book The Lonely City: Adventures in the Art of Being Alone, she focuses on the incredibly alluring quality of seclusion, and, at the same time, its dangerously addictive power over people in time of crisis. In the preface Laing writes that

[1]oneliness is difficult to confess; difficult too to categorise. [...] it can run deep in the fabric of a person [...]. Then again, it can be transient, lapping in and out in reaction to external circumstances, like the loneliness that follows on the heels of a bereavement, break-up or change in social circles. (Laing 2016, 3)

1 Cacioppo and Patrick give an engaging reading of loneliness and examine this phenomenon from evolutionary and psychological perspective. They claim that " $[\mathrm{t}]$ he pain of loneliness is a deeply disruptive hurt. The disruption, both physiological and behavioral, can turn an unmet need for connection into a chronic condition, and when it does, changing things for the better requires taking into account the full depth and complexity of the role loneliness plays in our biology and in our evolutionary history" (Cacioppo and Patrick 2008, 8). 
What Laing rightly notices is that being lonely, due to its intrinsically subjective character, is always difficult to specify. It differs depending on various social contexts like migration, political upheavals or personal experience and preferences. Yet, without a doubt, the feelings of isolation and despondency, whether they are internal or triggered by external factors, always cast a shadow on the character's development.

What was the attitude of the Victorians towards loneliness and its potential destructive features? On the one hand, they celebrated economic novelty and the development of cutting-edge technologies. Therefore, they had reasons to be optimistic about the future. They considered themselves to be the most advanced nation in the world. Yet, the most striking element in Victorian life was the existence of incredible disproportions between the poor and the rich. Victorian London saw a deluge of working-class people who sought employment and a new life as a result of which they were estranged from their small rural communities. Contemporary literature also provided some instances in which the protagonists experience aching loneliness. It is either caused by social estrangement (Tess of the d'Urbervilles: A Pure Woman Faithfully Presented by Thomas Hardy, published in 1891), the unsuccessful desire for education (Jude the Obscure, published in 1895), and the disconnection between what the character wants and what is required by the society (Far from the Madding Crowd, published in 1874). When one looks specifically at the feminine perspective, a heroine suffers as she is unable to find understanding within the society - she desires either autonomy or love and support. In other words, the unfulfilled need of agency shapes protagonists who struggle with feelings of loneliness since they are devoid of hope for any change of the situation (Hendry 2019, 2). Going back almost two hundred years to nineteenth-century Britain, the impact of alienation on the individual's psyche was indeed a sensitive and, at the same time, captivating topic. Writers, poets, and painters of the Victorian period, influenced by new medical discoveries, were constantly exploring the depths of human personality and its infinite complexity (Faas 2016, 29). They were praised for "the analysis of particular states of mind" and the attempts to make sense of them (Fox 1831, 214).

One of the poets who embarks on a journey of uncovering the mentality of his protagonists is Alfred, Lord Tennyson (1809-1892). In his works, he delves into the mind of a bored, disappointed king ("Ulysses"), a yearning noblewoman locked in a tower ("The Lady of Shalott"), or a disillusioned poet ("The Epic"). Not only does Tennyson portray their attitudes but also creates a wider context in which the characters are forced to operate. As a matter of fact, he constructs psychological scenery mostly by applying various deeply ingrained mythological references, the intriguing rhythm of language, and visually evocative descriptions.

The aim of this essay is to discuss the way Tennyson links psychology and poetics in his work "Mariana" while presenting the mental disintegration of the protagonist. As the poem unfolds, Tennyson shows the gradual psychological decay of Mariana's personality through different poetic modes of representation, namely: visual, especially regarding the use of colours and the description of a barren landscape; auditory, 
focusing on an overwhelming silence that drives the protagonist into madness, and temporal, in which the distortion of time seems to be an element of her fixation on abandonment. From the close reading of the poem it may be concluded that the character is stuck between conflicting emotions, which she is unable to confront. It could be also argued that the heroine herself is responsible for her mental downfall. Indeed, her inertia and stagnation, though poetically and aesthetically appealing, eventually destroy her psyche.

\section{The ekphrastic subtlety of "Mariana"}

Undoubtedly, one of Tennyson's most subtle poems that studies the mind is "Mariana," published in 1830 in the collection Poems, Chiefly Lyrical. On the surface, the poem is a depiction of a woman jilted by her lover. The poem starts with a short epigraph "Mariana in the moated grange" - a direct reference to William Shakespeare's Measure for Measure, in which one of the subplots deals with a heroine deserted by her betrothed. Yet, unlike the play, the lovers in the poem are not reunited. The possibility of his return is immediately discarded by the repetition of the words "[h]e cometh not" (1. 10), recurrently spoken by Mariana.

Tennyson does not simply resort to the use of emotional language to describe Mariana's predicament, but rather relies on the description of place and the general circumstances in which the protagonist has found herself. What is more, it is an ekphrastic poem, in which adjectives and descriptive words play a crucial role in building the overall mood. For instance, "[t]ill cold winds woke the gray-eyed morn" (1. 31), "[t]he cluster'd marish-mosses crept" (1. 41), or "the gusty shadow sway" (1.51) evidently create a gloomy aura in the poem. Verbs, if they appear, are often static and describe not the actions of the character but the surroundings. This approach is reflected in lines such as "[t]he rusted nails fell from the knots" (1. 3), "[t]he broken sheds look'd sad and strange" (1. 5), or "[t]he slow clock ticking" (1. 74). This clearly signifies that Mariana is not the one who plays the active part in controlling her fate; it seems that she is stripped of agency and unable to make her own choices. One of the readings of this could be that this change strongly emphasises some recurrent themes in Tennyson's works, namely the inability to connect with other human beings, the lack of communication within the society, and the fascination with withdrawal and isolation, which can manifest in mental disorders, ultimately leading to insanity.

In the poem, Tennyson employs an unusual lyrical mode, namely the third-person lyric, whose primary aim is the revelation of the state of the character's mind. As Boyd and William note, because the consciousness is driven predominantly by affective processes, "Mariana" can be labelled as "a mood poem" in which the strength of emotions is presented through rich descriptive language $(1983,582)$. Therefore, it is possible to read the poem as "the speaker's account of her tortured soul [and] the utterance of a subjective psychological condition" (Armstrong 1993, 12). However, in 
case of "Mariana," Tennyson, "instead of an 'I' or an impersonally recorded vision," renders the protagonist's inner life through the eyes of a distant observer who sees the "consciousness of an other" (Boyd \& Williams 1983, 582). Thus, the speaking persona is someone - as it were - standing outside, someone who refers to the character in the third person (she) but at the same time has access to the thoughts, feelings, and reasoning of these protagonists. Since the third person lyric appears not to be commonly used, readers may encounter a problem with establishing whose perspective is being described. It seems that the emotions are not experienced either by Mariana, or the poet himself, but these impressions form in the mind of the other observer who sees Mariana from the outside. The confusion regarding the speaker's point of view may arise also from the fact that the mood is not suggested by the poet or even Mariana but is ascribed to the speaking persona - "the mind of an other" (Boyd \& Williams 1983, 583 ), that is the observer in the poem. This could also indicate a preoccupation with the problem of viewpoint, namely the question of how to represent the consciousness of the protagonist in a different way, other than the first person lyric. ${ }^{2}$ In "Mariana," the third-person lyric aims to create an even bigger distance between the character herself and the observer who has insight into her psyche. Consequently, the ambiguities connected with perspective mirror even more complicated spheres in the protagonist's mind.

\section{Visual and auditory imagery as a mirror of psychological downfall}

A popular trend among the Victorian poets was the presentation of feelings and hidden desires via visual imagery. In Robert Browning's deeply disturbing poem "Porphyria's Lover," the raging storm mentioned at the beginning reflects a troubling mental state of the male protagonist. What is more, the correlation between visuals and psychology can be also traced in Thomas Hardy's poetry. In "During Wind and Rain" the change of seasons triggers a profound realisation that time works against human beings. Yet another example may be found in the works of Mathew Arnold, whose canonical poem "Dover Beach" might be interpreted in terms of religious doubt. Because it can be easier to express strong urges and deeply rooted fears by means of concrete images, Tennyson decided to implicitly convey claustrophobic isolation in his description of the landscape using the so-called pathetic fallacy. The term, coined by English art critic

2 While discussing the problems with identifying protagonist's point of view it seems interesting to note a similarity between "Mariana" and William Wordsworth's "The Thorn." The latter poem, published in Lyrical Ballads, shows how the transition of perspectives affects the reading. At first, the reader sees the narrator who characterises the thorn in detail. The description is marked by his subjective perception of reality as he struggles to understand Martha, the main character in the poem. In other words, the reader sees the narrator, who perceives the world around him, and who imbues the surrounding landscape with his own subjectivity. Ultimately, the thorn becomes a symbol of mourning, loss, and misery but all these sensations are filtered by the narrator. 
John Ruskin, is connected with the idea that inanimate objects, like the weather or the surroundings, have a tendency to reflect the emotional state of a speaking persona ("Of the Pathetic Fallacy," 1856). Decades later, the concept of transferring certain emotions into visual imagery re-emerged as the "objective correlative." The theory, proposed by T.S. Eliot, refers to the expression of feelings not by directly presenting one's state of mind but by showing a series of images that create a string of associations with a particular sensation. As Eliot writes in the essay "Hamlet and His Problem:"

[t]he only way of expressing emotion in the form of art is by finding an "objective correlative"; in other words, a set of objects, a situation, a chain of events which shall be the formula of that particular emotion; such that when the external facts, which must terminate in sensory experience, are given, the emotion is immediately evoked. (n. pag)

Ironically, the modernists strongly opposed the Victorian style of writing and yet the technique of objective correlative can be identified in the description of Mariana's situation. Tennyson moves away from the world of direct description of emotions and applies the concrete images which evoke specific feelings. Indeed, objective correlative aims at conjuring certain emotions via sensory stimuli, without telling the reader what the protagonist actually experiences. It means that a certain thing or element stands for a state of mind or sensation. That is why the source of the emotional reaction lies in the precise assembly of images. In "Mariana," one can notice elements of objective correlative since Tennyson uses a variety of objects which gradually start to communicate feelings of unutterable sadness and longing, without stating exactly what kind of gloom and desolation these are. The buildings on the farm are in dire condition, weeds envelop thatched roofs, and stagnant water lingers in the sluice. Everything is rusty and covered in dust. Moreover, Mariana's psychological state corresponds to the appearance of the moated grange, which is deserted and surrounded by black moss. The choice of words such as "moss" (1. 1) and "rusted" (1. 3), "weeded," "worn" (1. 7), "crusted" (1. 2), "broken" (1. 5), "mouldering" (1. 64) clearly implies a sense of decay and resignation, as if suggesting that Mariana has been neglected for years. Each minute element of the landscape evokes the woman's dejection. The grange, supposed to be full of life and vitality, is, in fact, a lonely place, marked by images of darkness, stillness, and unrealized potential. Water, which typically symbolises fertility, femininity, and rebirth (Cirlot 2001, "Water") ${ }^{3}$ is presented in the poem as "blackened" (1.38) and filthy. What is more, the use of enclosed space, either in the image of the grange or of the "wild winds [that] bound within their cell" (1. 54), shows Mariana's estrange-

3 In A Dictionary of Symbols J. E. Cirlot points out the vast symbolism of water. Apart from the modern understanding of it as a dynamic and specifically female aspect of personality, Cirlot makes the claim that water can also mean "the universal congress of potentialities" (2001, "Water") and stand for the source of life. What is more, water is characterised by its dual nature - on the one hand, it can signify death and destruction as in the biblical flood or rebirth and regeneration on the other, which is visible for instance in baptism. 
ment from society, and the lack of possibility or willingness to communicate with the external world (Gunter 1971, 64-65). The entrapment, both mental and physical, is also reflected in the poem's rhyme scheme. Each stanza consists of twelve lines with the rhyming sequence ababcddcefef and the central quatrain's rhyme structure ( $c d d c$ ) clearly indicates the imprisonment of the protagonist.

Another important visual factor that implies Mariana's psychological degradation is the specific use of colours that alludes to the festering of both nature and the character's psyche. For instance, the first stanza stresses the combination of black mould and green moss, which can be linked to the natural processes of blight and slow degeneration. The disgusting images of decomposition and rotting convey a doleful message with regard to the heroine's state of mind. They clearly contradict any possibility of change for the better or any hope for emotional healing. Relishing her misery, Mariana seems to be rotten to the core. ${ }^{4}$ Most certainly, black is the predominant colour in the poem. It seems to be a recurring theme; the descriptions of the surrounding landscape are marked by shades of blackness, e.g. "thickest dark did trance the sky" (1. 18) or "[a] sluice with blacken'd waters slept" (1.38). What is interesting, the alchemic blackness corresponds to the decay and the gradual disintegration of any substance in nature. Notably, the extensive use of black, seen as the absence of any colour whatsoever, can be read as related to psychological degradation accompanied by aching loneliness and omnipresent melancholia, which rule Mariana's life (Beidermann 1992, "Black"). Additionally, black seems to function "as one of the building blocks for a set of rhetorical techniques Tennyson utilizes to create the melancholic form of poetry" (Jakse 2014, 1). In fact, Tennyson himself acknowledged that the "black blood" ran in his family, thus showing that the subject of despondency seems to put a stamp on his own writing (Riede 2005, 41). ${ }^{6}$ Interestingly, blackness is closely related to the word melancholia,

4 It is interesting to compare the poem with Gerard Manley Hopkins's sonnet "Carrion Comfort." The poem is part of the so-called Terrible Sonnets, written around 1885-1886 which expressed Hopkins's isolation and possible depression due to several reasons: the conversion to Catholicism "spiritually alienated [him] from England" since Catholicism was not widely accepted, moving to Ireland physically separated Hopkins from his homeland. Poems included in Terrible Sonnets reflect deep suffering of the author but without succumbing to it. Although the poetic persona in "Carrion Comfort" openly admits to crippling depression, he also makes a firm assertion that giving in to despair would be like feasting on carrion: "Not, I'll not, carrion comfort, Despair, not feast on thee" (1. 1). A different attitude can be found in Tennyson's poem. Here, Mariana seems to indulge in her despair and persists in her hopelessness.

5 The Dictionary of Symbolism edited by Hans Beidermann describes black as a symbol of "the descent into darkness and mourning" (1992, "Black"). In fact, in European culture blackness has two conflicting associations - it signifies either occult powers, offering little hope for human beings, or a promise of final resurrection and ultimate transformation. Interestingly, as Beidermann notes, in Chinese cosmological stories blackness and water seem to intertwine. This could confirm Tennyson's intuition to apply this particular symbolism in the poem.

6 Tennyson's adolescent life was marked by troubled family relations. It was believed that the domestic mayhem amplified the genetic tendency towards gloom and feelings of utter despair. The 
which in Latin means "black blood," thus linking it with the medieval concept of humours, in which "black blood" was associated with depression (Jakse 2014, 1).

The use of visual aspects in the poem definitely sets the mood of Mariana's dreary predicament. A peculiar and unsettling combination of images creates a sense of utmost sorrow and unfulfilled potential. In order to achieve a gloomy aura, Tennyson used (unconsciously perhaps) the modernist technique of objective correlative, in which the artistic formula of images like blackened waters, thatched roofs, deserted moated grange and thickest dark evokes a sense of isolation and anguish. However, Tennyson goes even further; instead of relying solely on pictorial manifestations of psychological decay, he decided to incorporate a specific soundscape into his poem, consequently conjuring up a whole universe of Mariana's psyche.

Apart from extensive use of visual imagery, the poem relies heavily on sound and silence. As Lynne Pearce rightly observes, reading the poem aloud seems to be a profound experience itself as "the rhythm rocks, its refrain seduces" and the listener is "enchanted by the subtle modulations in its tone" $(1991,60)$. Truly, the hypnotic application of assonance and alliteration - for instance "dreary/aweary" $(1.10,12)$ or "sound/confound" $(1.74,76)$ - can make the reader even more lethargic. However, the rhythm also "tantalise[s] expectation much in the same way as Mariana is tantalised by the deferred hope of Angelo's return" (Pearce 1991, 61). Moreover, Tennyson uses feminine rhymes, which makes words such as "dreary" and "aweary" $(1.10,12)$ even more languorous and drawn-out.

Throughout the poem, the motif of silence as a destructive force in nature also relates to Mariana's mental condition. Apparently, the only words uttered repetitively by her are ones of despair and yearning for both love and death:

"My life is dreary,

He cometh not," she said;

She said, "I am aweary, aweary,

I would that I were dead!" (11. 9-12)

Mariana does not express herself through a sudden outburst of emotions or her artistic creation as the Lady of Shalott, Tennyson's other well-known heroine; instead, she resembles a catatonic wraith who is unable to speak for herself and simply wants to die. Indeed, without the ability to rebel and oppose her fate, she accepts her depression and destructive loneliness. ${ }^{7}$ For that reason, her psychological state could be

analysis of depression, which ran in Tennyson's family, can be found in Laurence W. Mazzeno's Alfred Tennyson: The Critical Legacy (Woodbridge: Boydell and Brewer, 2004).

7 Yet another example of a woman stricken by grief and unable to deal with abandonment can be found earlier, in the Romantic period. In "The Ruined Cottage" William Wordsworth tells a story about a woman left by her husband. Her psychological downfall caused by the incredible loss is mirrored in the presentation of the cottage - shattered, neglected, and crumbling down. What seems to be a crucial element is the quiet desperation of Margaret, the main protagonist. As 
labelled as a "melancholy madness," which - as a Victorian psychiatrist James Cowles Prichard claimed - combines moroseness with insanity $(1835,32)$. What is more, the reader may immediately notice the ubiquitous silence. Even the slightest sound is exaggerated, thus becoming overwhelming and almost unbearable: rusted nails that fall, the clinking latch, shrieking of mice, birds singing quietly and ticking clocks, even the flutter of the flies' wings (Boyd \& Williams 1983, 592) all work to emphasise the surrounding stillness. One may conclude that the oversensitivity to sounds brings Mariana to the brink of madness caused by alienation from other human beings.

\section{Time as a destructive force}

Another theme that may signify the protagonist's psychological downfall is the pervasive preoccupation with time. The reader may observe the inevitable passing of time by the presence of rust or moss in the grange and its destructive influence. Moreover, Mariana's perception of time seems to be utterly distorted.

First, she speaks the same words ("He cometh not"), constituting an agonising loop, expressing nothing but perpetual misery connected with her isolation. In this she might resemble, to some extent, Charles Dickens's Miss Havisham, the abandoned bride-to-be from Great Expectations (the novel was published in 1861, much later than "Mariana"), who is unable to let go of the ghosts of the past. It is not a triumphant celebration of her misery. In fact, she chooses to re-enact the same pattern to persuade herself that the affair had never happened. In both cases, the disappointment over rejected love has a pernicious effect on both female characters and the only way to cope with the tragedy is to retreat into solitary madness. In the novel, Miss Havisham becomes almost a monstrous figure whose decay seems to be all-encompassing. The images of the destroyed wedding dress that she would never remove from her body, or the rotting cake left uneaten on the table, make the reader uncomfortable, sickened and even repulsed by her suffering. While Miss Havisham's downfall is both physical and psychological, Mariana's disintegration is purely mental; as a matter of fact, the poem does not mention her appearance. The only thing the reader may infer would be that the protagonist's soul collapses but not the body. It serves to notice that this feature rarely shows in the nineteenth-century painterly representations of the poem: for instance, John Everett Millais presented her as a blasé, bored but graceful woman, not a scruffy or a sordid character. In Millais's painting, Mariana looks rather elegant, stylised as a medieval lady, yet with a Victorian middle-class aura around her.

As a matter of fact, Tennyson and Dickens showed interest in the position of women in the patriarchal culture which left no place for women who were neither wives

Wordsworth writes "Five tedious years / She lingered in unquiet widowhood, / A wife and widow" (11. 446-448). That is to say, Margaret's slow disintegration, caused by sorrow and disappointment, is subtly reflected by the decay of the house. 
nor mothers. As Elaine Showalter remarks, the Victorians had problems with positioning women who did not conform to the ideals of the Victorian family bliss, labelling them as "redundant," "odd," and prone to mental disorders $(1985,61)$. As Victorian women wrote in their diaries and novels, without managing the house and children there was a small range of meaningful occupations; hence the frequent occurrence of mental breakdowns. ${ }^{8}$ The suffocating influence of family and social ties prevented women from working and searching for meaning outside of household life. Indeed, boredom, the accumulation of small frustrations, and inertia ultimately led to nervous breakdowns. Most certainly, passivity, deprivation of purposeful occupation and defining one's worth through social and personal relationships often left women subject to mental disintegration.

The second indication of the protagonist's fixation is her view of time. Boyd and Williams notice that the passing of time is present in the poem but "only with the agonising slowness of an hour hand, so that process and stasis seem equally palpable" $(1983,585)$. They remark that time is not conceptualised as linear but rather as cyclical, as is visible in the following stanza:

Her tears fell with the dews at even;

Her tears fell ere the dews were dried;

She could not look on the sweet heaven,

Either at morn or eventide. (11. 13-16)

Cyclical time very often signifies processes of life, death, and ultimate rebirth. It tends to emphasise the patterns and repetitions within the natural world such as the seasonal changes, the phases of the moon, the day/night cycle, which serve as a basic point of reference in our understanding of reality. This conceptualisation also brings another implication as it offers a possibility of renewal. In the case of "Mariana," the cyclical perception of time brings only disappointment as she is stuck in time and, in her view, cannot be redeemed. Scholars also note that this passage illustrates a paradoxical "stasis-within-motion" (Boyd \& Williams 1983, 586). The slow change between night and day is further subdivided, creating a loop of smaller, separate temporal stages in which Mariana is eternally entangled. As another critic writes, in Mariana's eyes temporality is monotonous; in fact, time passes without any meaning whatsoever (Kissane 1965, 88). There seems to be no future for her, as the key words "he cometh not" (1. 10) emphasise absolute resignation and lack of hope for change or any final resolution.

8 Elaine Showalter discusses the case of Florence Nightingale, a famous nurse whose contribution to the Crimean War was invaluable. Showalter points out that Nightingale struggled with depression since her family insisted on her being married and she was not encouraged to pursue a career as a nurse. As a result, Nightingale started to have suicidal thoughts and she thought she was going mad (Showalter 1985, 63). 
The climax of Mariana's psychological disintegration is reached in the last stanza. Until the final part, her emotions influence the way she looks at nature, whereas in the last stanza it is the view of the landscape that affects her mental state. The chirrup of the birds, the ticking of the clock and the setting sun make her loathe evening as another day has passed and nothing has changed. However, the smooth rhythm, which seems to flow throughout the poem is disrupted. The enjambment in lines 76-77, where the sounds of nature "confound / Her sense", indicates a precise moment of realisation that hope is gone and Mariana is driven mad by her grief and disappointment. What is noteworthy, the refrain is changed in the final line "Oh God, that I were dead!" (1. 84), implying a kind of an ending - either of her life or her resolution not to wait for her lover.

All in all, the poem appears to be an account of the gradual psychological decay of the heroine due to her isolation from the outside world. It was a well-established trend in Victorian poetry to portray a psychological landscape in the form of a dramatic monologue, which Tennyson was no stranger to; in fact, he was one of the pioneers of the genre. ${ }^{9}$ Nonetheless, he decided to take a different approach. He incorporates different modes of imagery to convey the atmosphere of a deserted moated grange that mirrors Mariana's inner life. Through evocative visual descriptions of the landscape as well as the use of colour symbolism, Tennyson paints a picture of Mariana's mental deterioration and depression. Not only does he use the ekphrastic mode in portraying her psyche, but he also creates a soundscape in which the heroine's auditory perception becomes even more oppressive and burdensome. Moreover, Mariana's inertia and stasis may be interpreted as an implicitly reluctant acceptance of her fortune and the inability to act in order to change her life. As Boyd and William rightly suggest, Tennyson seems to portray a silent suffering since Mariana's "speechlessness seems quintessentially part of [her] grief, isolation, and hopeless passivity" (Boyd \& Williams 1983, 590). Truly, if Tennyson decided to reveal her state of mind through her own speech, then it might have ruined the intended sombre mood of the poem. As a matter of fact, Mariana speaks only in rare outbursts of emotions, thus emphasising even more the silence around her. Furthermore, the pervasive quietness allows the female protagonist to express what cannot be articulated with words. What is interesting is that the distortion of time resulting from the character's subjectivity may suggest her fixation on temporality and, in the case of Mariana, its destructive aspects. ${ }^{10}$

9 In his seminal work Retreat into the Mind: Victorian Poetry and the Rise of Psychiatry, Ekbert Faas investigates the relationship between literature, early psychology and aesthetics, focusing especially on the works of nineteenth-century poets such as Wordsworth, Browning and Tennyson. As Faas writes, "Victorian critics, unlike their twentieth-century successors, viewed the dramatic monologue as essentially the poetry of psychology. They spoke of mental or psychological monologues and of poems of a new dramatic-psychological kind, while even tracing the new genre to Romantic poetry" (Faas 2016, 12).

10 Another interesting example of a poem that relies on the interplay between stasis and passing of time is John Keats's “To Autumn." Contrary to Tennyson's poem, Keats represents the blissful 


\section{"Mariana" as a reinterpretation of the Gothic heroine}

Even though the poem seems to be Victorian at the core, it is tempting to treat Mariana as a reinterpretation of the late-eighteenth-century Gothic heroine. On the one hand, she is trapped in a gloomy, remote place, waiting patiently to be saved by her beloved. Certainly, her helplessness, vulnerability, and inability to change her predicament are part of a typical construct in Gothic novels. Nonetheless, Mariana is not a fully-fledged Gothic protagonist. She is not young or innocent - it is not the lack of experience that destroys her but her blind naivety about love. Perhaps she should have embarked on a journey to discover herself, similarly to the young heroines from Mrs Radcliff's novels, who encounter several obstacles that shape their characters, thus becoming more mature and self-conscious. However, she decides to dwell in her dire situation and false innocence. Moreover, there is no clearly established villain. Who is the enemy? Is it the lover who does not come back? Or is it Mariana herself? One reading of the poem may be that the protagonist's voice is weak as she focuses only on the absence of her lover. As Melissa Buron argues, Mariana's feelings and mental state are tightly linked to her beloved without him she does not exist, as it were. Her whole world revolves around her pining and longing for male appreciation (Buron 2003). Instead of being an independent heroine who sets out on a long and painful journey of self-recognition, Mariana chooses to be overly fixated on her emotions. This behaviour can be treated as a symptom of the destruction of herself. She is neither wed nor single, she is neither Angel of the House nor a fallen woman. ${ }^{11}$ Therefore, she lingers in a liminal space, without any resolution whatsoever. For this reason, the reader, instead of judging Mariana's abnormal behaviour, sympathises with her and sees her as a pitiful character and a victim of circumstance. ${ }^{12}$

It might also mean that Mariana's in-betweenness causes her to be positioned outside the Victorian social order. As a matter of fact, not only Gothic but also postmodern genres tend to play with various aspects of liminality. In The French Lieutenant's Woman by John Fowles, the main protagonist, Sarah, cannot be easily labelled, either by the gentleman Charles Smithson, society or even the reader. The first indicator of her borderline state is the fact that she is a woman who was born in the lower class (as a farmer's daughter) but her education allows her to aspire to the middle class. The other thing the reader knows from the very beginning of the novel is that Sarah has got a bad reputation because of premarital sex, which was considered outrageous in the Victorian times. In fact, she broke the Victorian social norms as she was neither a submissive or virginal Angel in the House, nor a fallen woman (in one of the endings she lives with her daughter),

idea of death and the passing of time as something inevitable, soothing, with the full acceptance of decay and death.

11 The theme of transgression in Tennyson's "Mariana" is further explored by Andrea Ryan in Gender Politics in Alfred, Lord Tennyson's Early Poetry (1999, MA Thesis, MacMaster University).

12 Literary scholars have continuously investigated readers' responses to certain narratives and the particular role of empathy in reception of literature. Techniques of empathy in literary works are further discussed by Suzanne Keen in "A Theory of Narrative Empathy" (Narrative 14, No. 3, 2006). 
nor a prostitute who succumbs to moral degradation. Being a feminine rebel and a woman expelled from society, Sarah is allowed to express herself freely since there are no expectations imposed on her. However, the other protagonist, Ernestina, who complies with the Victorian norms of being a perfect wife and mother, never wishes to change her fate and accepts it, realising how superficial her feelings towards her fiancé Charles are.

As Elaine Showalter shows in her analysis of female maladies, particularly depression and hysteria, withdrawal from the world, as one of "feminine forms of protest," was "far less effective than action and rebellion" (Showalter 1985, 65). That is to say, women of the nineteenth century, who felt trapped in the Victorian social order, started to develop their own language of opposition by utilizing silence and inertia. Yet, for Victorian psychiatrists a typical madwoman at that time was the delicate one, disappointed and wounded by love, not a rebel who wanted to change her position in the social structure (Showalter 1985, 90).

\section{Conclusion}

Harold Bloom gives a provocative reading of the poem, claiming that "Mariana" is "deliciously unhealthy [...], the finest example in the language of an embowered consciousness representing itself as being too happy in its unhappiness to want anything more" (quoted in Everett's "Alfred Tennyson's 'Mariana"'). Bloom notices the cruel irony of the poem, namely how dwelling in one's misery makes one embrace it. In psychological terms, what Mariana feels can be labelled as melancholia, particularly in the modern, twentieth-century understanding. In the essay "Mourning and Melancholia" Sigmund Freud distinguishes the two notions signalled in the title. Although both are ways of dealing with loss, they operate in slightly different ways. According to Freud, mourning is a natural reaction to the physical absence of a loved person; it is a normal process in which a person has to recover from the traumatic experience of being left behind. On the other hand, Freud sees melancholia as an abnormality, a condition in which a person cannot pinpoint precisely what was lost, thus making it pathological in the Victorian social context. In relation to the discussed poem, Mariana seems to represent the latter as she dwells in this state voluntarily, or, as Freud writes, "it is the sadism alone [...] which makes the melancholia so interesting - and so dangerous" (Freud 1917, 252). In other words, Bloom seems to use some of the psychoanalytical notions in his criticism as he notes the seductive power of pathological melancholia, which mixes pleasure and pain in the experience of loss.

As shown above, Mariana's psychological disintegration, despite being visually compelling, without any signs of decay, appears to be still lamentable. Truly, the core of Mariana's tragedy is this vicious circle of the love-hate relationship with her situation. She wants to change her predicament, but she is unable to do so. Having experienced a personal crisis, she decided to retreat to a solitary place and re-evaluate her situation but without any success. As far as language is concerned, it can be argued that labelling the 
poem as "deliciously unhealthy" and stating that her unconscious appears to be "too happy in [her] unhappiness to want anything more" (Bloom quoted in Everett) seems to be an exaggeration; indeed, there is nothing delicious about the rotting of the landscape that mirrors the protagonist's psyche; actually, it reinforces her masochistic coping mechanisms. It can resemble a white sepulchre - beautiful on the outside yet rotten and devastated inside. Bloom seems to perceive Mariana as a repressed poetess whose position can flourish only when her beloved is gone. As Bloom writes "What would she do with him, what mental space has she left for him?" (Bloom 1976, 153). In that sense, "Mariana" is analysed in terms of the author's poetic invention. Of course, Bloom rightly notices that "Mariana" can be interpreted in terms of Romantic crisis-ode, where intense emotions during a personal crisis would prevail. However, he focuses on a Freudian and rhetorical reading of the poem, not on a symbolic or psychological one. Even though the musical structure of the poem may possess a lullaby-quality due to the assonance, the rhyming scheme clearly refers to the entrapment of a female psyche in the patriarchal society as well as physical detachment from community. What is more, the choice of lexis reflects the destruction, disintegration, and passage of time, showing the inevitable decay of the natural world, including herself.

The imagery is not as poignantly graphic as in the presentation of Miss Havisham. Above all, the power of the poem lies not in the immediate shock and disgust, but in evoking a sense of moroseness, inertia and stasis, which slowly kills the protagonist. As demonstrated above, Tennyson skilfully links often abnormal mental states with beautifully crafted imagery. Bearing this in mind, it is possible to see that "Mariana" focuses on conveying the mood through a psychological landscape, not through a particular narrative. Images of darkened water, destroyed grange, moated surroundings add a sombre tone to the poem. Additionally, Mariana is presented as a quasi-gothic heroine - defenceless, naïve, and pure but without the drive to change her condition. Instead, she chooses to linger in misery, making her life psychologically unbearable yet poetically and visually appealing.

It can be argued that there seems to be a pattern in depicting women in Victorian literature. Historically, Victorian women had to suffer long years of limitations, either in economic terms or private spheres, enduring inequalities imposed by the Victorian patriarchal society. Nonetheless, literature of that time provides a wide array of feminine protagonists - from angelic, self-sacrificing Amy Dorrit in Charles Dickens's Little Dorrit or the quasi-femme fatale in D.G. Rossetti's poem "Lady Lillith" to an aspiring feminist from Aurora Leigh and the victim of circumstance in Robert Browning's "Porphyria's Lover." Certainly, in the majority of cases, the feminine character is seen through the eyes of a male narrator; therefore, her inner life is filtered through masculine perception. This may suggest that the female voice in the Victorian poetry was still very often repressed or not fully represented as women wanted it to be. Nevertheless, securing feminine independence and promoting gradual economic separateness were gradually advanced as vital agendas, leading to the creation of a New Woman at the end of the nineteenth century. 


\section{References}

Armstrong, Isobel. 1993. Victorian Poetry: Poetry, Poetics and Politics. London: Routledge.

Beidermann, Hans. 1992. Dictionary of Symbolism. New York: Facts On File.

Bloom, Harold. 1976. Poetry and Repression: Revisionism from Blake to Stevens. New Haven and London: Yale University Press.

Bragg, Melvyn. 2014. “The Philosophy of Solitude.” Podcast. In Our Time. Accessed October 27, 2018. https://www.bbc.co.uk/programmes/b046ntnz

Boyd, John D., and Anne Williams. 1983. “Tennyson's 'Mariana' and Lyric Perspective.” Studies in English Literature, 1500-1900 23 4: 579 - 593. doi: 10.2307/450264

Buron, Melissa E. 2003. "The Feminine Voice and the Feminine Presence in Nineteenth-Century Poetry." The Victorian Web. Accessed October 27, 2018. http://www.victorianweb.org/ authors/rb/buron14.html

Cacioppo, John and William Patrick. 2008. Loneliness: Human Nature and the Need for Social Connection. New York, London: W. W Norton \& Company.

Cirlot, Juan Eduardo. A Dictionary of Symbols, 2nd ed., s.v. "Water." Abington: Taylor \& Francis e-Library.

Eliot, Thomas Stearns. 1921. "Hamlet and His Problem." The Sacred Wood. New York: Alfred A. Knopf. Accessed October 26, 2017. https://www.bartleby.com/200/sw9.html

Everett, Glen. 2004. “Alfred Tennyson's 'Mariana'.” The Victorian Web. Accessed January 18, 2018. http://www.victorianweb.org/authors/tennyson/mariana.html

Faas, Ekbert. 2016. Retreat into the Mind: Victorian Poetry and the Rise of Psychiatry. Princeton: Princeton University Press.

Fox, W. J. 1831. "Poems, chiefly Lyrical by Alfred Tennyson" Westminster Review 14. London: Robert Heward.

Freud, Sigmund. 1917. "Mourning and Melancholia." The Standard Edition of the Complete Psychological Works of Sigmund Freud. London: The Hogarth Press.

Gunter, G. O. 1971. "Life and Death Symbols in Tennyson's Mariana”. South Atlantic Bulletin 36 3: 64-65. doi: 10.2307/3197412.

Hendry, Marie. 2019. Agency, Loneliness, and the Female Protagonist in the Victorian Novel. Newcastle upon Tyne: Cambridge Scholars Publishing.

Hopkins, Gerard Manley. 1885-7. "Carrion Comfort.” Poetry Foundation. Accessed February 13, 2018. https://www.poetryfoundation.org/poems/44392/carrion-comfort

Jakse, Vanessa. 2014. The Black Blood of the Tennysons: Rhetoric of Melancholy and the Imagination in Tennyson's Poetry. MA Thesis. Cleveland State University.

Keats, John. 1820. “To Autumn.” Poetry Foundation. Accessed January 29, 2019. https://www. poetryfoundation.org/poems/44484/to-autumn

Keen, Suzanne. 2006. "A Theory of Narrative Empathy." Narrative 14 3: 207-236. Project MUSE, doi:10.1353/nar.2006.0015

Kissane, James. 1965. "Tennyson: The Passion of the Past and the Curse of Time." ELH 32 1: 85-109. doi: 10.2307/2872373. 
Pobrane z czasopisma New Horizons in English Studies http://newhorizons.umcs.pl Data: 26/04/2023 14:04:50

"Then thickest dark did trance the sky": a representation of psychological decay... 89

Laing, Olivia. 2016. The Lonely City: Adventures in the Art of Being Alone. Edinburgh: Canongate Books Ltd.

Mazzeno, Laurence W. 2013. Alfred Tennyson: The Critical Legacy. Cambridge: Cambridge University Press.

Pearce, Lynne. 1991. "Mariana: Gorgeous Surfaces.” Woman/Image/Text: Readings in Pre-Raphaelite Art and Literature. 59 - 69. Toronto: University of Toronto.

Prichard, James Cowles. 1835. A treatise on insanity and other disorders affecting the mind. London: Sherwood, Gilbert, and Piper.

Riede, David G. 2005. Allegories of One's Own Mind: Melancholy in Victorian Poetry. Columbus: The Ohio State University Press.

Ruskin, John. 1856. "Of The Pathetic Fallacy.” Modern Painters. Vol. 3. n. pag. Our Civilisation.org. Accessed January 18, 2018. https://www.ourcivilisation.com/smartboard/shop/ ruskinj/

Ryan, Andrea. 1999. Gender Politics in Alfred, Lord Tennyson's Early Poetry. MA Thesis. MacMaster University.

Showalter, Elaine. 1985. The Female Malady: Women, Madness and English Culture, 18301980. New York: Pantheon Books.

Tennyson, Alfred. 1968. "Mariana.” In The Norton Anthology of English Literature, ed. M.H. Abrams. New York: W.W. Norton,. 1112.

Wordsworth, William. 2003. "The Thorn." In Wordsworth and Coleridge Lyrical Ballads and Other Poems. Ware: Wordsworth Editions Ltd. 52-59.

---. "The Ruined Cottage." 2003. In Wordsworth and Coleridge Lyrical Ballads and Other Poems. Ware: Wordsworth Editions Ltd. 95-108. 